\section{Tania Maria Brasil Esteves'}

Regina Paiva Daumas'

Maria Inês Couto de Oliveira"

Carlos Augusto de Ferreira de Andrade ${ }^{\text {III }}$

Iuri Costa Leite ${ }^{\mathrm{IV}}$
Centro de Saúde Escola Germano Sinval Faria. Escola Nacional de Saúde Pública Sergio Arouca. Fundação Oswaldo Cruz. Rio de Janeiro, RJ, Brasil

Departamento de Epidemiologia e Bioestatística. Instituto de Saúde da Comunidade. Universidade Federal Fluminense. Niterói, RJ, Brasil

III Laboratório de Epidemiologia Clínica. Instituto de Pesquisa Clínica Evandro Chagas. Fundação Oswaldo Cruz. Rio de Janeiro, RJ, Brasil

Departamento de Epidemiologia e Métodos Quantitativos. Escola Nacional de Saúde Pública Sergio Arouca. Fundação Oswaldo Cruz. Rio de Janeiro, RJ, Brasil

\section{Correspondence:}

Tania Maria Brasil Esteves

Fundação Oswaldo Cruz

Rua Leopoldo Bulhões, 1480 térreo

Manguinhos

21041-210 Rio de Janeiro, RJ, Brasil

E-mail: tmbesteves@gmail.com

Received: $12 / 3 / 2013$

Approved: 3/7/2014

Article available from: www.scielo.br/rsp

\section{Factors associated to breastfeeding in the first hour of life: systematic review}

\section{Fatores associados à amamentação na primeira hora de vida: revisão sistemática}

\begin{abstract}
OBJECTIVE: To identify independent risk factors for non-breastfeeding within the first hour of life.
\end{abstract}

METHODS: A systematic review of Medline, LILACS, Scopus, and Web of Science electronic databases, till August 30, 2013, was performed without restrictions on language or date of publishing. Studies that used regression models and provided adjusted measures of association were included. Studies in which the regression model was not specified or those based on specific populations regarding age or the presence of morbidities were excluded.

RESULTS: The search resulted in 155 articles, from which 18 met the inclusion criteria. These were conducted in Asia (9), Africa (5), and South America (4), between 1999 and 2013. The prevalence of breastfeeding within the first hour of life ranged from $11.4 \%$, in a province of Saudi Arabia, to $83.3 \%$ in Sri Lanka. Cesarean delivery was the most consistent risk factor for non-breastfeeding within the first hour of life. "Low family income", "maternal age less than 25 years", "low maternal education", "no prenatal visit", "home delivery", "no prenatal guidance on breastfeeding" and "preterm birth" were reported as risk factors in at least two studies.

CONCLUSIONS: Besides the hospital routines, indicators for low socioeconomic status and poor access to health services were also identified as independent risk factors for non-breastfeeding within the first hour of life. Policies to promote breastfeeding, appropriate to each context, should aim to reduce inequalities in health.

DESCRIPTORS: Breast Feeding. Infant, Newborn. Postpartum Period. Review. Epidemiologic Studies. 


\section{RESUMO}

OBJETIVO: Identificar fatores de risco independentes para a não amamentação na primeira hora de vida.

MÉTODOS: Revisão sistemática nas bases de dados Medline, Lilacs, Scopus e Web of Science, sem restrição de idioma ou período de publicação, até 30 de agosto de 2013. Foram incluídos estudos que utilizaram modelos de regressão e forneceram medidas de associação ajustadas. Foram excluídos artigos que não especificaram o modelo de regressão utilizado ou que abordaram populações específicas quanto à faixa etária ou presença de morbidade.

RESULTADOS: Foram identificados 155 artigos, dos quais 18 preencheram os critérios de inclusão. Foram realizados na Ásia (nove), África (cinco) e América do Sul (quatro) entre 1999 e 2010. A prevalência da amamentação na primeira hora de vida variou de 11,4\%, em uma província da Arábia Saudita, a 83,3\% no Sri Lanka. A cesariana foi o fator de risco mais consistente para a não amamentação na primeira hora de vida. "Baixa renda familiar", "idade materna menor que 25 anos", "baixa escolaridade materna", "ausência de consultas pré-natais", "parto domiciliar", "falta de orientação sobre amamentação no pré-natal" e "prematuridade" foram fatores de risco identificados em pelo menos dois estudos.

CONCLUSÕES: Além de rotinas hospitalares, indicadores associados a pior nível socioeconômico e menor acesso a serviços de saúde foram também identificados como fatores de risco independentes para a não amamentação na primeira hora de vida. Políticas de promoção da amamentação, adequadas a cada contexto, devem ter como meta a redução das desigualdades em saúde.

DESCRITORES: Aleitamento Materno. Recém-Nascido. Período PósParto. Revisão. Estudos Epidemiológicos.

\section{INTRODUCTION}

Breast milk provides all of the nutrients an infant needs for the first six months. Additionally, it has immunological properties that protect infants against common diseases, such as diarrhea and pneumonia, which are important causes of infant morbidity and mortality.,18,22 Breastfeeding also presents advantages to the mother's health, increasing the postpartum infertility period, helping them return to their pregestational weight, and reducing their risk of developing breast ${ }^{6}$ and ovarian cancer. ${ }^{13,25,49}$

Despite its recognized benefits, the practice of breastfeeding, in the majority of countries, is still below the recommended by the World Health Organization (WHO). ${ }^{20}$ Regarding promotion of breastfeeding, the WHO recommends placing newborns in direct contact with their mothers immediately after birth for at least one hour, and encourage the mother to initiate breastfeeding as soon as the newborn is ready, offering help if necessary. ${ }^{58}$ This recommendation is based on the newborn's stronger aptitude in spontaneously searching for the nipple area and initiating breastfeeding during this period, contributing to the establishment of exclusive maternal breastfeeding. ${ }^{54,57}$
Breastfeeding in the first hour of life is associated with prolonged duration of breastfeeding ${ }^{33,34}$ and reduction of infant mortality, especially in low-income countries. ${ }^{2,9,23}$ The positive effects of breastfeeding on the newborn's health can be attributed to the components of breast milk, as well as the contact between mother and baby. The colostrum, milk on its first days, contains the epidermal growth factor, which accelerates the development of the intestinal mucus, as well as the immunological bioactive factors that provide immunological protection to the newborns, preventing intestinal colonization by pathogenic microorganisms. ${ }^{5,37}$

The "skin to skin" contact between mother and newborn immediately after birth favors the newborn's skin colonization by the mother's microbiota, facilitates the regulation of body temperature, maintains the blood glucose levels stable, and contributes to cardiorespiratory stability. ${ }^{33,55}$ The suction of the nipple right after birth stimulates the secretion of prolactin and oxytocin, hormones that induce the production and ejection of milk. ${ }^{28,54}$ The oxytocin also reduces 
puerperal bleeding and accelerates uterine involution, presenting additional benefits to the mother. ${ }^{15}$

In the past two decades, following WHO recommendation, the timely initiation of breastfeeding has been getting more attention from managers and researchers that work on questions relative to breastfeeding and infant nutritional practices. The inclusion of the question about the time between birth and the initiation of breastfeeding in the Demographic and Health Survey (DHS) has generated similar studies in several countries, as well as comparisons between them. ${ }^{8}$ However, no systematic review uniting the body of evidence about the factors that promote or inhibit the opportune initiation of breastfeeding exists.

The objective of the present study was identifying independent risk factors for non-breastfeeding in the first hour of life.

\section{METHODS}

A systematic literature review utilizing pre-established protocol for the search, selection, and extraction of data was performed. The articles were found through bibliographic searches of the following databases: Medline, consulted via PubMed, ${ }^{\mathrm{a}}$ Lilacs, ${ }^{\mathrm{b}}$ Scopus, ${ }^{\mathrm{c}}$ and Web of Science. ${ }^{\mathrm{d}}$ The description of this systematic review is based on the guidelines of the Preferred Reporting Items for Systematic Reviews (PRISMA). ${ }^{24}$

The strategy for searching the PubMed database used the following terms: ("first hour" [Title/Abstract]) OR("delayed initiation" [Title/Abstract]) OR ("timely initiation" [Title/Abstract]) AND ("breast feeding" [Title/Abstract]) OR ("breastfeeding" [Title/Abstract]). Similar strategies were adopted for the other databases. No limits were set with regard to time of publication or language restriction and the searches were finalized on August 30, 2013. Then, the reference lists of the selected articles were analyzed to identify other eligible publications.

The considered inclusion criteria comprised observational studies analyzing the determinants of breastfeeding or non-breastfeeding in the first hour of life, utilizing regression models with the intention of obtaining adjusted association measurements. Articles in which the type of regression model was not specified and studies that approached specific populations on the basis of the mother's age or the presence of mother or newborn morbidities were not included for preserving the comparison among the selected studies.
The references obtained through the electronic search were stored with the assistance of the program EndNote X7.0.1, through which duplicates were then excluded. Two independent reviewers evaluated the abstracts of the references obtained. All the publications that were potentially eligible were selected for full text reading. The extraction of data and final classification regarding inclusion into the review were done independently, the results were compared and the disagreements were resolved through a consensus between the two reviewers, or by a third reviewer, when necessary.

The following were recorded in the data extraction file: the complete reference of the article, location (country/city) where the study was conducted, period and data collection scenario, sample size, project design, prevalence of breastfeeding in the first hour, inclusion and exclusion criteria of individuals, analyzed variables, results found, and the points value for the quality evaluation criteria.

The quality of the studies was evaluated according to an instrument adapted from the Newcastle-Ottawa Scale for the evaluation of cohort studies ${ }^{\mathrm{e}}$ and considering the STROBE guidelines for sectional studies. ${ }^{26}$ Four items were evaluated, receiving one point each, when they reached the standard of reference: means of selecting participants (S): representative and descriptive sample of the target population as complete, random or selective; loss proportion $(\mathrm{P})$ : described and inferior to $20.0 \%$; means of standardizing the outcomes (D): standardization instruments available or described; and selection of variables for statistical analysis (A): gross estimates presented and selection criteria of variables for the final model described.

As the outcome for the majority of articles was "nonbreastfeeding in the first hour of life", the results of all the studies were converted to this outcome. The variables that presented significant statistical association $(\mathrm{p}<0.05)$ with the outcome in adjusted regression models were considered risk factors when they resulted in the increase of chance or prevalence of non-breastfeeding in the first hour of life and factors of protection when resulted in the reduction of the chance or prevalence of this outcome. The terms "opportune initiation" and "delayed initiation" were also utilized in this study to refer, respectively, to the start of breastfeeding at the first hour of life and after that period.

The variables associated with breastfeeding in the first hour of life were classified, according to its proximity to the outcome, in four hierarchical levels of determination: ${ }^{51}$

\footnotetext{
a PubMed: the bibliographic database [Internet]. Bethesda: National Library of Medicine; [s.d.]. Available from: http://www.ncbi.nlm.nih.gov/pubmed b LILACS: Literatura Latino-Americana e do Caribe em Ciências da Saúde [Internet]. São Paulo: Bireme; [s.d.]. Available from: http://lilacs. bvsalud.org/

c Scopus [Internet]. Elsevier; Amsterdan; [s.d.].

${ }^{\mathrm{d}}$ Web of Science [Internet]. Thomson Reuters Scientific. New York; [s.d.].

e Wells G, Shea B, O'Connell D, Peterson J, Welch V, Losos M, et al. The Newcastle-Ottawa Scale (NOS) for assessing the quality if nonrandomized studies in meta-analyses. Ontario; [s.d.] [cited 2013 Feb 1]. Available from: http://www.ohri.ca/programs/clinical_ epidemiology/oxford.htm
} 
contextual (occasion of birth and geographical location), distal (familiar and maternal characteristics), intermediate (pregnancy and prenatal care characteristics) and proximal (delivery care and newborn characteristics).

\section{RESULTS}

The electronic search produced a total of 323 references, of which 168 were removed due to repetition. Of the 155 titles/summaries evaluated, 107 were excluded for not meeting the pre-established criteria and 48 were selected for full text reading (Figure 1). Five articles were added from the reference lists of the articles read, resulting in a total of 53 studies read completely. Two thirds of the studies (35) were excluded for not being observational (four), utilizing another definition for opportune initiation (over one hour) (nine), not describing the regression model used (one), not presenting adjusted association measurements (nineteen), or presenting incomplete results (two). In the last case, although the authors were contacted, the missing results were not obtained. At the end of this process, 18 studies fulfilled the inclusion criteria. Table 1 presents the main characteristics of the 18 articles that were included in ascending order according to the study period. Seventeen studies were sectional and only one $\mathrm{e}^{36}$ identified itself as a cohort.

Half of the studies (nine) were carried out in Asia, five in Africa, and four in South America (Brazil). These studies were conducted between 1999 and 2010. The majority of the studies analyzed information derived from residential surveys (11), six of which utilized data from the DHS, carried out between 2000 and 2010. The maximum age of the child, at the time of the interview, varied between two days and two years. The smallest sample was composed of 262 participants ${ }^{35}$ and the largest had 10,317. ${ }^{39}$

The prevalence of breastfeeding in the first hour of life varied from $11.4 \%$ in a province of Saudi Arabia ${ }^{10}$ to $83.3 \%$ in Sri Lanka. ${ }^{45}$ Among the studies that were carried out in communities or in clinics, the smallest proportion of home births was found in Saudi Arabia $(0.0 \%)^{10}$ and the largest was found in a survey in Ethiopia $(93,8 \%) .{ }^{16}$ The number of cesarean sections varied from $2.1 \%$ in an survey performed in the rural areas of Ethiopia ${ }^{48}$ to $49.3 \%$ in a hospital sample in the city of Rio de Janeiro. ${ }^{1}$

Most studies used logistic regression as the multivariate method of analysis. One of the studies utilized logistic

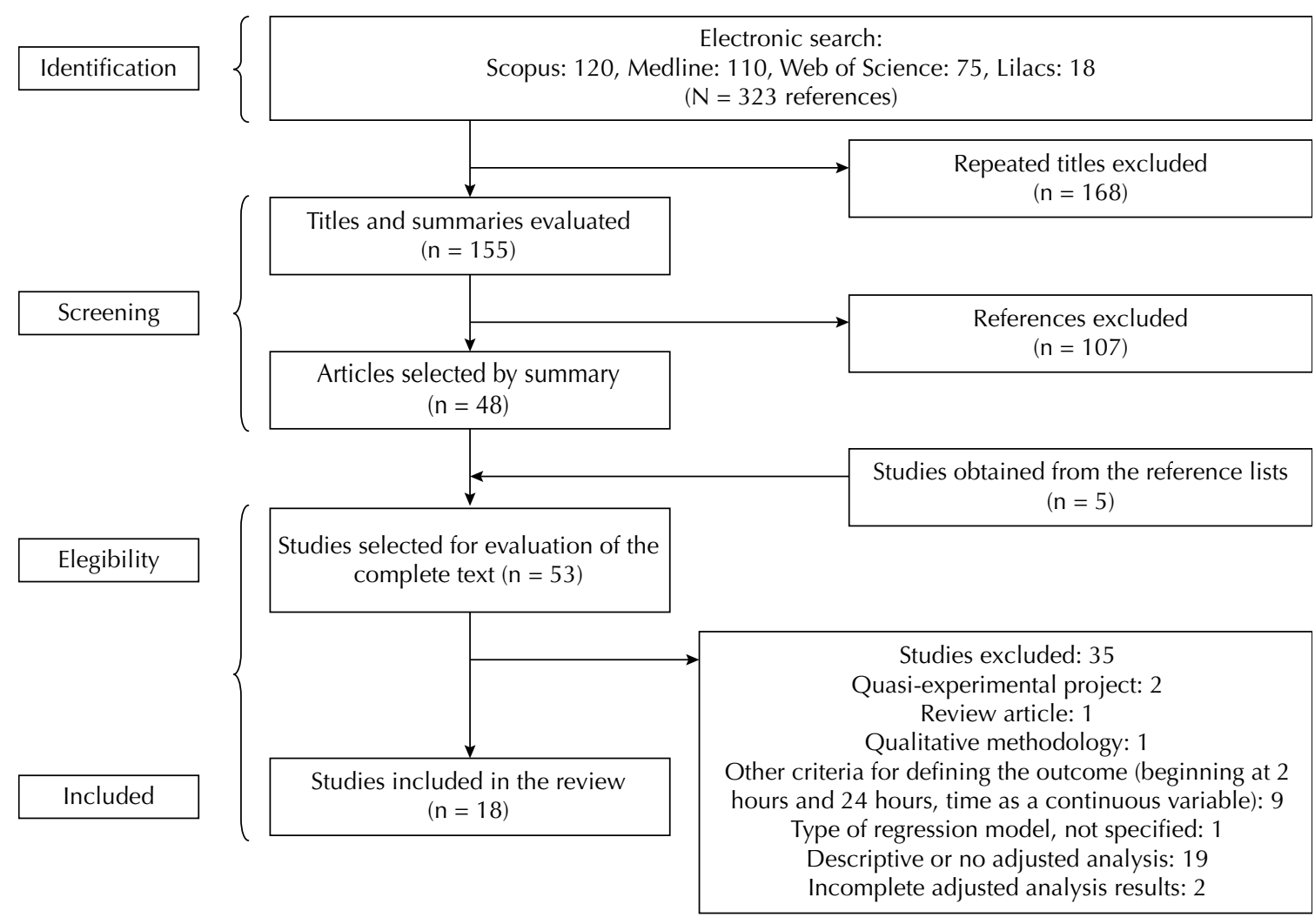

Figure 1. Flow Chart of the Selection Process for the Studies to be Included in the systematic review on the risk factors for non-breastfeeding in the first hour of life. 


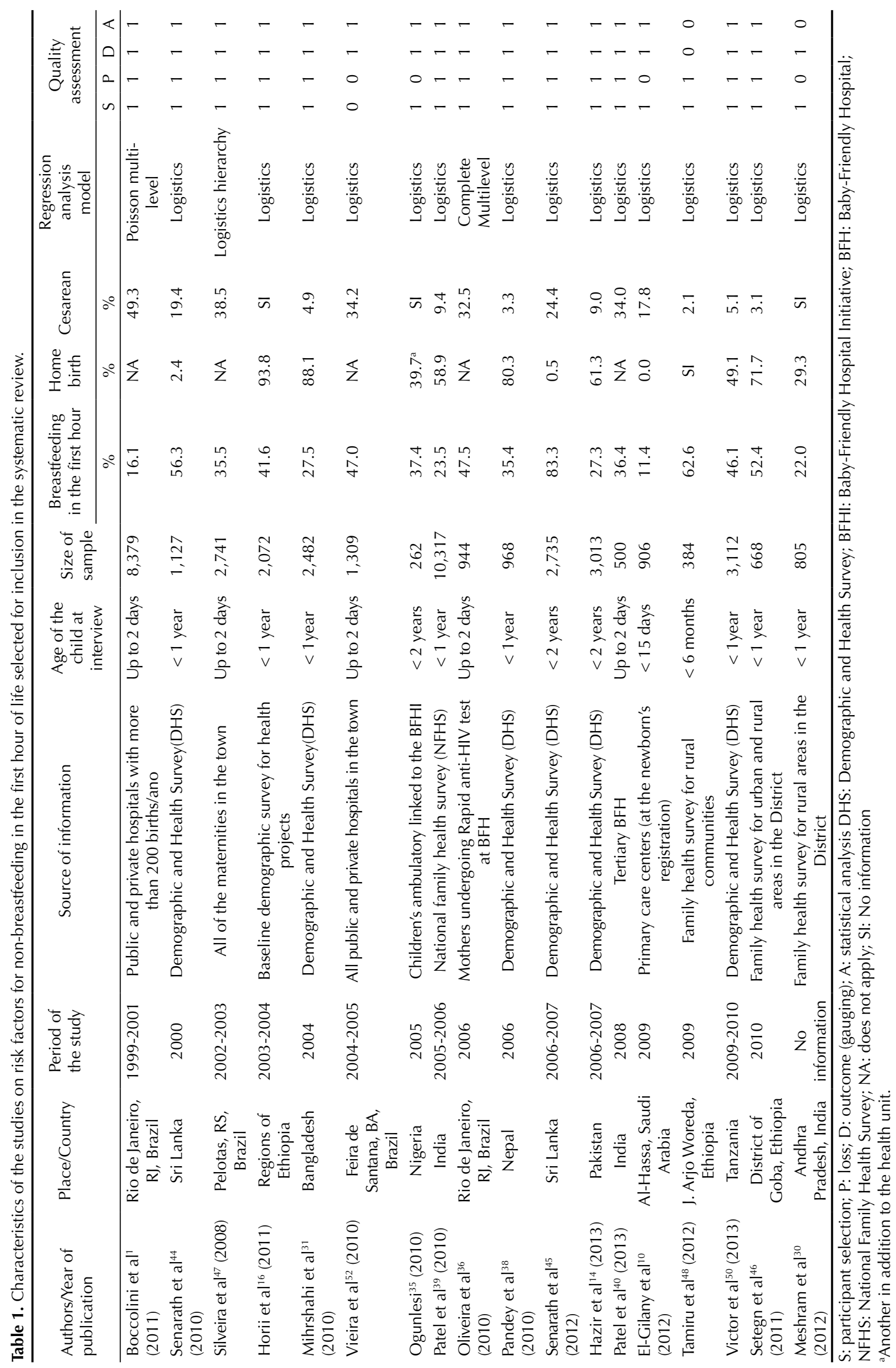


regression in a hierarchal model ${ }^{47}$ and another applied Poisson's multilevel regression. ${ }^{1}$ Only the cohort study used a multilevel complementary log-log model. ${ }^{36}$ With regard to the quality of the studies, 13 of the 18 articles obtained the maximum score for the criteria evaluated.

Table 2 shows the variables classified as risk or protection factors or not associated to non-breastfeeding in the first hour of life, as well as the number of times each variable has been investigated.

At the contextual level, breastfeeding in the first hour of life has been associated to the geographical residence zone in most of the studies that investigated this variable. Living in a rural area was a risk factor in two studies carried out in African countries ${ }^{46,50}$ and a protection factor in two Asian studies. ${ }^{10,31}$

At the distal level, which reflects the maternal familiar and sociodemographic characteristics, the following were identified as independent risk factors: low family income $(3 / 13),{ }^{30,31,45}$ maternal low schooling level $(4 / 17),{ }^{39,40,48,50}$ and maternal low income $(1 / 1){ }^{36}$

A brazilian study has associated low schooling to protection (1/17) ${ }^{47}$ Maternal employment was found to be a risk factor in two studies ${ }^{14,50}$ and a protection factor in one out of nine studies. ${ }^{39}$ Maternal age was not associated to the outcome in the majority of the studies (11/14). However, extreme (higher and younger) maternal ages were occasionally associated with larger risk. ${ }^{39,47,50}$

At the intermediate level (pregnancy and prenatal attention), three studies ${ }^{31,35,39}$ identified the access to antenatal clinic visits as a protection factor for breastfeeding in the first hour of life. Other factors, such as the mother receiving a prescription for iron ${ }^{16}$ and guidance about breastfeeding ${ }^{40,52}$ at the consultations as well as receiving home visits, were also eventually identified as factors of protection.

At the proximal level, defined by the newborn's characteristics and the care received during labor, the variables related to labor were most frequently associated with non-breastfeeding at the first hour of life. Home delivery was a risk factor for delayed initiation of breastfeeding in four out of 11 studies..$^{35,39,45,50}$ Delivery assisted by a family member, when compared with delivery assisted by health professionals, increased the risk of non-breastfeeding during the first hour of life in Tanzania, ${ }^{50}$ while delivery assistance by family members or trained midwives was associated to timely initiation of breastfeeding in a study done in Ethiopia. ${ }^{16}$

Cesareans showed to be a risk factor for non-breastfeeding in the first hour of life in 11 of 14 studies investigated. In hospital-based studies, the hospitals characteristics, such as the source of financing ${ }^{1}$ and its certification by the Baby-Friendly Hospital Initiative (BFHI), ${ }^{47}$ have also been associated with the outcome. Mothers receiving the results of the rapid anti-HIV test after birth was identified as a risk factor in the only study in which variables related to the anti-HIV tests were investigated..$^{36}$ The baby receiving prelacteal food ${ }^{10}$ and the mother having breast issues (pain, engorgement, cracks) ${ }^{10,48}$ were factors associated to delayed initiation of breastfeeding in some studies.

Among the variables related to the child, the following were identified as risk factors: prematurity $(2 / 3),{ }^{40,52}$ low

Table 2. Risk and protection factors and those not associated to non-breastfeeding in the first hour of life in the selected articles.

\begin{tabular}{|c|c|c|c|c|}
\hline Variable & Risk & Protection & Not associated & Number of studies \\
\hline \multicolumn{5}{|l|}{ Contextual level } \\
\hline Rural residential area & 46,50 & 0,31 & $14,35,38,39,44$ & 9 \\
\hline Residential geographic area & $14,39,50$ & $31,38,39,45$ & 44 & 8 \\
\hline Child's highest age on the date of the interview & 45 & 39 & $14,30,31,44$ & 6 \\
\hline \multicolumn{5}{|l|}{ Distal level } \\
\hline Low family income & $30,31,45$ & & $10,14,36,38,39,40,44,47,50,52$ & 13 \\
\hline Nuclear family & & 30 & & 1 \\
\hline Father's schooling level & & & $14,31,38,39,47$ & 5 \\
\hline Mother's age ( in years) & & & & 14 \\
\hline$<20$ or $<25$ & 39,50 & & 1,52 & \\
\hline$\geq 35$ (versus $20-34)$ & 47 & & $10,14,31,35,36,38,44-46$ & \\
\hline Mother's highest schooling level & 47 & $39,40,48,50$ & $1,10,14,30,31,35,36,38,39,44-46,52$ & 17 \\
\hline Low maternal income & 36 & & & 1 \\
\hline Non-white ethnicity & 36 & 47 & 1 & 3 \\
\hline Caste (scheduled ${ }^{\mathrm{a}}$ ) & & 30 & & 1 \\
\hline
\end{tabular}

Continue 


\begin{tabular}{|c|c|c|c|c|}
\hline \multicolumn{5}{|l|}{ Continuation } \\
\hline Mother's profession & 14,50 & 39 & $10,31,36,38,44,45$ & 9 \\
\hline Mother's occupation & & & $35,38,46$ & 3 \\
\hline Body mass index & & & $31,38,39,45,50$ & 5 \\
\hline Mother's decision-making power & & 38 & $31,39,44,45,50$ & 6 \\
\hline Listens to the radio & & 39 & $31,48,50$ & 4 \\
\hline Watches television & & & $31,39,50$ & 3 \\
\hline Reads the newspaper & & & $31,39,50$ & 3 \\
\hline Marital status & & & $1,14,31,36,38,39,44,48,50$ & 12 \\
\hline Multiparous & & 10 & $1,14,16,31,35,36,38,39,44-47,50,52$ & 15 \\
\hline Interval between births & & & $14,31,38,39,45,46$ & 6 \\
\hline \multicolumn{5}{|l|}{ Intermediate level } \\
\hline Obstetric problem (toxemia or hemorrhaging) & 40 & & & 1 \\
\hline Smoking while pregnant & & & 1,47 & 2 \\
\hline Access to prenatal health care & & $31,35,39$ & $14,16,36,38,40,44,45,47,48,50$ & 13 \\
\hline Iron prescribed at dr. visit & & 16 & & 1 \\
\hline Orientations regarding breastfeeding & & 40,52 & $1,16,46$ & 5 \\
\hline Home visit & & 44 & 45,46 & 3 \\
\hline \multicolumn{5}{|l|}{ Proximal level } \\
\hline Home birth & $35,39,45,50$ & & $14,16,30,31,38,44,46$ & 11 \\
\hline Birth assisted by family member ${ }^{b}$ & 50 & 16 & $31,38,39,44,48$ & 7 \\
\hline Birth assisted by trained midwife & & 16 & 50 & 2 \\
\hline Cesarean & $1,14,36,38-40,44,45,47,50,52$ & & $10,31,46$ & 14 \\
\hline Private hospital birth & 1 & & 10 & 2 \\
\hline BFH birth & & 47 & & 1 \\
\hline Postdelivery breastfeeding counseling & & 46 & & 1 \\
\hline Unaware of undergoing rapid anti-HIV test & & 36 & & 1 \\
\hline Unaware of the anti-HIV test results & & 36 & & 1 \\
\hline Receiving anti-HIV test result post birth & 36 & & & 1 \\
\hline State that health care professionals do not listen to her & 36 & & & 1 \\
\hline I don't want to breastfeed in the labor & 36 & & & 1 \\
\hline Newborn received prelacteal foods & 10 & & & 1 \\
\hline Newborn was not presented to the mother once born & 1 & & & 1 \\
\hline Time until postnatal check-up & & & $31,38,39$ & 3 \\
\hline Breast problems (pain/fissures) & 10,48 & & & 2 \\
\hline Female sex & & 45 & $1,10,14,16,30,31,38,39,44,46,50$ & 12 \\
\hline Size of newborn (mother's perception) & & & $14,39,40$ & 3 \\
\hline Prematurity & 40,52 & & 10 & 3 \\
\hline Low birth weight & 45 & & $10,40,44,52$ & 5 \\
\hline Apgar 0 to 7 in the $5^{\text {th }}$ minute & 48 & & & 1 \\
\hline Inter-occurrance immediately postpartum & 1 & & & 1 \\
\hline
\end{tabular}

BFH: Baby-Friendly Hospital

a Scheduled castes: set of disfavored and catalogued castes as determined in the Constitution of India as potential beneficiaries of affirmative actions.

${ }^{\mathrm{b}}$ Births not assisted by health professionals.

Variables evaluated in only one study, with no significant association included: basic sanitation, relationships between people and items, desire to become pregnant, abortion attempt, father's support during pregnancy, physical abuse during pregnancy, prenatal adaptation (opportune start and number of visits), company in the delivery room, use of oxytocin during the during labor, assessment of care at delivery, multiple births, congenital anomaly; ${ }^{1}$ mother brought a bottle to the hospital and intends on using it; ${ }^{47}$ socioeconomic level (chronic malnutrition); ${ }^{16}$ father's occupation; ${ }^{50}$ information about breastfeeding in the media, newborn cried immediately at birth; ${ }^{40}$ prior breastfeeding experience, educational sessions; ${ }^{52}$ trimester of pregnancy in which anti-HIV test was performed, receiving result of pre-natal anti-HIV test before birth; ${ }^{36}$ family planning and health education; ${ }^{48}$ admission to neonatal ICU. ${ }^{10}$ 


\begin{tabular}{|c|c|c|c|c|}
\hline & & Age & $\begin{array}{l}\text { Contextual Factors } \\
\text { Residential geographic area } \\
\text { Urban/rural residential area } \\
\text { child when interview (time of birth) }\end{array}$ & \\
\hline $\begin{array}{l}\text { Distal level } \\
\text { Family } \\
\text { characteristics } \\
\text { Income level } \\
\text { Nuclear family } \\
\text { Maternal } \\
\text { characteristics } \\
\text { Ethnicity } \\
\text { Age } \\
\text { Schooling } \\
\text { Occupation } \\
\text { Income } \\
\text { Parity } \\
\text { Information on } \\
\text { breastfeedin }\end{array}$ & $\sqrt{1}$ & $\begin{array}{l}\text { Intermediate level } \\
\text { Characteristics at } \\
\text { pregnancy } \\
\text { Obstetric problems } \\
\text { during pregnancy } \\
\text { Prenatal care } \\
\text { characteristics } \\
\text { Number of doctor's } \\
\text { visits } \\
\text { Guidelines to } \\
\text { breastfeeding } \\
\text { Home visits }\end{array}$ & $\begin{array}{l}\text { Proximal level } \\
\text { Characteristics of labor care } \\
\text { Hospital birth } \\
\text { Assistance at birth } \\
\text { Hospital financing } \\
\text { Birth at a Baby-Friendly Hospital } \\
\text { Type of labor } \\
\text { Knowledge of submission for anti-HIV testing } \\
\text { Moment of anti-HIV test results } \\
\text { Mothers feel that are heard by health staff } \\
\text { Mother wanting to breastfeed in the delivery } \\
\text { room } \\
\text { Newborn given to mother immediately after } \\
\text { birth } \\
\text { Characteristics of the babies } \\
\text { Gestational age } \\
\text { Birth weight } \\
\text { Intercurrences of postpartum } \\
\text { Sex }\end{array}$ & $\begin{array}{l}\text { Breast feeding } \\
\text { in the first } \\
\text { hour of life }\end{array}$ \\
\hline
\end{tabular}

${ }^{\text {a }}$ Adapted from Boccolini et al' (2010).

Figure 2. Representation by hierarchical level of the risk factors for breastfeeding in the first hour of life. ${ }^{a}$

birth weight $(1 / 5),{ }^{45}$ immediate postpartum complications $(1 / 1),{ }^{1}$ and an Apgar index below eight on the fifth minute $(1 / 1) \cdot{ }^{47}$ Being of the female sex has proved be a protection factor in one of the studies $(1 / 12) .{ }^{45}$

The graphic representation of the variables defined as associated with the outcome in at least one study is depicted in Figure 2 for better comprehension of the determination levels and the relationships among them.

\section{DISCUSSION}

Cesarean was the risk factor most consistently associated to non-breastfeeding in the first hour of life. Characteristics such as low family income, mother's age below 25 years, mother's low schooling level, absence of antenatal clinic visits, home birth, lack of prenatal guidance in regard to breastfeeding and prematurity were identified as risk factors in at least two studies.

Cesarean has been appointed as an important barrier to breastfeeding initiation (before or after the first hour) ${ }^{41,43}$ and is usually associated to routines of postoperative care which delay or interrupt the contact between the mother and her newborn in the postpartum period. ${ }^{27}$ Some authors suggest that behavioral factors are also involved in this relationship, in a way that mothers who have been submitted to cesareans would have lower predisposition for breastfeeding. ${ }^{42,53}$ This hypothesis is reinforced by Prior et al's ${ }^{42}$ (2012) meta-analysis, in which the largest risk of non-breastfeeding has been found only in elective cesareans.

Although the WHO advocates that the rate of cesareans should not surpass $10.0 \%$ to $15.0 \%,{ }^{56}$ rates much superior to this were reported in all hospital-based studies, while rates lower than $5.0 \%$ were found in places with poor access to health services. ${ }^{14,31,39,46,48,50}$ Indeed, the rate of cesareans is on the rise in the entire world, having reached to $52.0 \%$ in Brazil in the year of 2010, motivating governmental politics with the intention of reducing elective cesarians. ${ }^{32}$

The professionals' knowledge and the practices applied by health services seem to be the most important factors determining the initiation of breastfeeding after deliveries at hospitals, ${ }^{1,41}$ where the mother's decision-making power seems to be limited. In Brazil, private maternities have been associated to larger risks for delayed initiation of breastfeeding, ${ }^{1}$ while $\mathrm{BFHI}^{47}$ accreditation has been considered a protection factor. Inadequate routines, such as the delivery of anti-HIV rapid test result after child birth, have also contributed to delayed breastfeeding initiation among women who were submitted to these tests. ${ }^{36}$ 
In places where home delivery is more frequent, the knowledge and beliefs of the mother, family members, and midwives are factors that exert a larger influence on breastfeeding initiation. The inadequate knowledge of traditional midwives and family members concerning the benefits of early breastfeeding initiation is one of the possible causes for the worst performance of this indicator in home deliveries..$^{35,39,45,50}$ Negative cultural beliefs about the colostrum may constitute a barrier in rural parts of Africa ${ }^{46,50}$ and India. ${ }^{30,40}$ In the Setegn et $\mathrm{al}^{46}$ (2011) study, $35.0 \%$ of mothers pumped and discarded the colostrum for believing that it would jeopardize the baby and cause cramps, and that it is hard to digest. The delayed breastfeeding initiation not only deprives the child from the protective properties of the colostrum but also becomes the reason for premature introduction to prelacteal feeding. ${ }^{46}$

Family income, schooling, and age of mother were not independent determinants in most studies, possibly for having their effects mediated by factors closer to the outcome, also included in the models. However, in the studies that found an association of breastfeeding with income, the larger risk for delayed initiation of breastfeeding occurred amongst women with low income. The same has been observed in relation to low schooling level, with exception to the study of Silveira et $\mathrm{al}^{47}$ (2008), in which the higher schooling was identified as a risk factor for non-breastfeeding at the first hour of life. It is possible that this apparent disagreement is a result of the authors' adoption of a hierarchal model of analysis, ${ }^{51}$ in which the effects of schooling have been adjusted by variables of the same levels, but not by variables related to birth, considered closer to the outcome. The use of private maternities and the larger rate of cesareans could explain, in part, the biggest risk of late initiation of breastfeeding among women with higher schooling levels.

The risk of delayed breastfeeding among younger women reported by two of the studies ${ }^{39,50}$ concurs with other studies regarding the factors associated to the beginning of breastfeeding. ${ }^{7}$ It is possible that this finding is related to the larger inexperience and insecurity among these mothers; however, the fact that there is no difference between multiparous and nulliparous challenges this hypothesis.

Prenatal assistance should comprise comprehensive care (attention, prevention, and promotion of health). In the present review, different indicators of access (number of consults) and quality (prescription of iron, guidance about breastfeeding, and home visits) of prenatal care have been identified as factors associated to the early beginning of breastfeeding. The information about breastfeeding that health professionals convey to the pregnant woman during prenatal period would favor the preparation for breastfeeding. ${ }^{52}$ Bueno \& Teruya ${ }^{3}$ (2004) state that adequate prenatal follow-up, counseling for the practice of breastfeeding, encouragement and support may contribute to early breastfeeding in the delivery room.

Among the factors related to children, premature babies ${ }^{40,50}$ or those born with low weight ${ }^{45}$ had significantly lower chances of opportune breastfeeding than those born full term. The need for special care may justify part of this result, but it is important to recognize and avoid unnecessary hospital practices to which this group is particularly vulnerable. Studies have identified immediate complications with the baby postpartum ${ }^{1}$ and an index of Apgar below eight in the fifth minute ${ }^{29}$ as risk factors for the delay in breastfeeding initiation. However, most hospital studies have excluded newborns with health problems.

Except for one study conducted in Saudi Arabia, ${ }^{10}$ all of the studies were conducted in low or mediumincome countries, ${ }^{\mathrm{f}}$ which suggests that this subject has not received much attention amongst the rich countries, where child survival is not threatened by the use of breastmilk substitutes. Meanwhile, the prevention of childhood obesity and allergic diseases, ${ }^{49}$ and even obesity and hypertension in adult life, ${ }^{17}$ are configured in health benefits that may present particular importance to these countries.

With respect to the quality of the studies, it has been observed that all the studies scored in at least two of the four criteria evaluated and the majority presented maximum scores. While quality evaluation is a fundamental step during the elaboration of a systematic review, there is no consensus as to what is the best instrument that can be used, ${ }^{19}$ making the evaluation of observational studies to be considered particularly complex. In the present review, an adapted instrument from the Newcastle-Ottawa Scale has been used, containing four items relative to sample selection, losses, information on outcome measurement and statistical analysis. Although very simple, the description of the obtained results in these criteria provides the reader with useful information for appreciation of the quality of the articles.

The current review did not investigate a specific exposure - outcome relationship, but covered different exposures, mapping the set of variables investigated as potential predictors of breastfeeding in the first hour of life and classifying them by hierarchical level of determination. Thereby, its results contribute to the comprehension of the involved processes for its occurrence in different contexts, but do not allow for a definite conclusion on the strength of the associations that were found.

i The World Bank. Country and lending group. Washington (DC);[s.d.] [cited 2013 Sept 1]. Available from: http://data.worldbank.org/about/ country-classifications/country-and-lending-groups 
There are certain limitations of the current study that should be considered. Although we elaborated broad search strategies, there is always the possibility of not capturing all the studies relevant to the case. Despite the quantitative synthesis by means of meta-analysis being the most objective form of presenting the results of a systematic review, it was not feasible in this case, as there was large heterogeneity among studies regarding the contexts in which they were produced and the variables that were analyzed. ${ }^{21}$ Employing this method to combine study results would lead to imprecise and inadequate summary measures.

Another limitation is related to the design of the primary studies. Almost all of the studies included in this revision were sectional $(17 / 18=94.4 \%)$, considered more fragile to the determination of causality for not guaranteeing the temporal cause - effect sequence. ${ }^{12}$ In fact, some associations reported may represent a situation of reverse causality in which the supposed outcome is the cause of the alleged exposure. Thus, the associations of non-breastfeeding in the first hour of life with "pre-milk feeding" and "breast problems"10,48 probably reflect situations of this type, as these occurrences normally surge after the first hour of life. One last question refers to the validity of information regarding the outcome. The fact that it was obtained from mothers up to two years after birth increases the risk of measurement error and recall bias in many of the evaluated studies.

Besides hospital routines, in the current review, indicators referring to the low socio-economic level and lower access to health services were also identified as independent risk factors for non-breastfeeding in the first hour. Despite scientific evidence and international recommendations to put the newborn close to the mother's body to initiate breastfeeding right after birth, ${ }^{57}$ the implementation of this practice still finds social and cultural barriers.

To reverse this situation, politics of breastfeeding promotion, appropriate to each context, must be developed and have the reduction in health inequality as its goal. In this sense, it is necessary to practice the WHO recommendations for the hospital routines ${ }^{58}$ and expand the access to prenatal care, birth assistance, and health information.

Regarding health services, the discussion of care routines, in light of the current scientific evidence, may offer professionals the necessary safety to abandon practices now known as harmful to the health of newborns. Considering the importance of family and social support, information about the benefits and practice of breastfeeding should be given not only to pregnant women but also to the population in general. The training of midwives and health community agents is equally strategic. Interventions that blend educational actions, structural changes in health services, and media campaigns tend to present better results in the promotion of breastfeeding. ${ }^{11}$

It is expected that the results presented here significantly contribute to the debate on the timely initiation of breastfeeding, enabling the amplification of knowledge over its determinants and planning interventions that facilitate its practice.

\section{ACKNOWLEDGMENTS}

To Dr. Maria de Fátima Moreira Martins Correa, for her contributions to the electronic database searches and identification of articles.

\section{REFERENCES}

1. Boccolini CS, Carvalho ML, Oliveira MIC, Vasconcellos AG. Factors associated with breastfeeding in the first hour of life. Rev Saude Publica. 2011;45(1):69-78. DOI:10.1590/S0034-89102010005000051

2. Boccolini CS, Carvalho ML, Oliveira MIC, PérezEscamilla R. Breastfeeding during the first hour of life and neonatal mortality. J Pediatr (Rio J). 2013;89(2):131-6. DOI:10.1016/j.jped.2013.03.005

3. Bueno LG, Teruya KM. The practice of breastfeeding counseling. I Pediatr (Rio J). 2004;80(5 Suppl):S126-30. DOI:10.1590/S0021-75572004000700003

4. Cesar JA, Victora CG, Barros FC, Santos IS, Flores JA. Impact of breast feeding on admission for pneumonia during post neonatal period in Brazil: nested casecontrol study. BMJ. 1999;318(7194):1316-20. DOI:10.1136/bmj.318.7194.1316

5. Chirico GR, Marzollo S, Fonte CC, Gasparoni A. Anti-infective properties of human milk. J Nutr. 2008;138(9):1801-6.

6. Collaborative Group on Hormonal Factors in Breast Cancer. Breast cancer and breastfeeding: collaborative reanalysis of individual data from 47 epidemiological studies in 30 countries, including 50302 women with breast cancer and 96973 women without the disease. Lancet. 2002;360(9328):187-95. DOI:10.1016/S0140-6736(02)09454-0

7. Dennis CL. Breastfeeding initiation and duration: a 1990-2000 literature review. J Obstet Gynecol Neonatal Nurs. 2002;31(1):12-32. DOI:10.1111/j.1552-6909.2002.tb00019.x

8. Dibley MJ, Roy SK, Senarath U, Patel A, Tiwari K, Agho KE, et al. Across-country comparisons of selected infant and young child feeding indicators and associated factors in four South Asian countries. Food Nutr Bull. 2010;31(2):366-75. 
9. Edmond KM, Zandoh C, Quigley MA, AmengaEtego S, Owusu-Agyei S, Kirkwood BR. Delayed breastfeeding initiation increases risk of neonatal mortality. Pediatrics. 2006;117(3):e380-6. DOI:10.1542/peds.2005-1496

10. El-Gilany AH, Sarraf B, Al-Wehady A. Factors associated with timely initiation of breastfeeding in AlHassa province, Saudi Arabia. East Mediterr Health J. 2012;18(3):250-4.

11. Fairbank L, O'Meara S, Renfrew MJ, Woolridge M, Sowden AJ, Lister-Sharp D. A systematic review to evaluate the effectiveness of interventions to promote the initiation of breastfeeding. Health Technol Assess. 2000;4(25):1-171.

12. Flanders WD, Lin L, Pirkle JL, Caudill SP. Assessing the direction of causality in cross-sectional studies. Am J Epidemiol. 1992;135(8):926-35.

13. Gwinn ML, Lee NC, Rhodes PH, Layde PM, Rubin GL. Pregnancy, breast feeding, and oral contraceptives and the risk of epithelial ovarian cancer. J Clin Epidemiol. 1990;43(6):559-68. DOI:10.1016/0895-4356(90)90160-Q

14. Hazir T, Akram DS, Nisar YB, Kazmi N, Agho KE, Abbasi $S$, et al. Determinants of suboptimal breast-feeding practices in Pakistan. Public Health Nutr. 2013;16(4):659-72. DOI:10.1017/S1368980012002935

15. Heinig MJ, Dewey KG. Health advantages of breast feeding for infants: a critical review. Nutr Res Rev. 1996;9(1):89-110. DOI:10.1079/NRR19960007

16. Horii N, Guyon AB, Quinn VJ. Determinants of delayed initiation of breastfeeding in rural Ethiopia: Programmatic implications. Food Nutr Bull. 2011;32(2):94-102.

17. Horta BL, Bahl R, Martines JC, Victora CG. Evidence on the long-term effects of breastfeeding: systematic reviews and meta-analysis. Geneva: World Health Organization; 2007.

18. Jones G, Steketee RW, Black RE, Bhutta ZA, Morris SS, Bellagio G. How many child deaths can we prevent this year? Lancet. 2003;362(9377):65-71. DOI:10.1016/S0140-6736(03)13811-1

19. Jüni $P$, Altman $D$, Egger M. Assessing the quality of randomized controlled trials. Systematic reviews in health care meta-analysis in context. London: BMJ Books; 2001.

20. Kramer MS, Kakuma R. Optimal duration of exclusive breastfeeding. Cochrane Database Syst Rev. 2002;(1):CD003517.

21. Kung J, Chiappelli F, Cajulis OO, Avezova R, Kossan $\mathrm{G}$, Chew L, et al. From systematic reviews to clinical recommendations for evidence-based health care: validation of revised assessment of multiple systematic reviews (R-AMSTAR) for grading of clinical relevance. Open Dent J. 2010;4:84-91.

22. Lamberti LM, Walker CLF, Noiman A, Victora CG, Black RE. Breastfeeding and the risk for diarrhea morbidity and mortality. BMC Public Health. 2011;11 Suppl 3:S15. DOI:10.1186/1471-2458-11-S3-S15
23. Lawn JE, Cousens S, Zupan J; Lancet Neonatal Survival Steering. 4 million neonatal deaths: when? Where? Why? Lancet. 2005;365(9462):891-900. DOI:10.1016/S0140-6736(05)71048-5

24. Liberati A, Altman DG, Tetzlaff J, Mulrow C, Gotzsche PC, loannidis JP, et al. The PRISMA statement for reporting systematic reviews and meta-analyses of studies that evaluate healthcare interventions: explanation and elaboration. BMJ. 2009;339:b2700. DOI:10.1136/bmj.b2700

25. Luan NN, Wu QJ, Gong TT, Vogtmann E, Wang YL, Lin B. Breastfeeding and ovarian cancer risk: a metaanalysis of epidemiologic studies. Am J Clin Nutr. 2013;98(4):1020-31. DOI:10.3945/ajcn.113.062794

26. Malta M, Cardoso LO, Bastos FI, Magnanini MM, Silva CM. STROBE initiative: guidelines on reporting observational studies. Rev Saude Publica. 2010;44(3):559-65. DOI:10.1590/S0034-89102010000300021

27. Matthews MK. The relationship between maternal labour analgesia and delay in the initiation of breastfeeding in healthy neonates in the early neonatal period. Midwifery. 1989;5(1):3-10. DOI:10.1016/S0266-6138(89)80058-0

28. Mercer JS, Erickson-Owens DA, Graves B, Haley MM. Evidence-based practices for the fetal to newborn transition. J Midwifery Womens Health. 2007;52(3):262-72. DOI:10.1016/j.jmwh.2007.01.005

29. Merewood A, Brooks D, Bauchner H, MacAuley L, Mehta SD. Maternal birthplace and breastfeeding initiation among term and preterm infants: a statewide assessment for Massachusetts. Pediatrics. 2006;118(4):e1048-54. DOI:10.1542/peds.2005-2637

30. Meshram II, Laxmaiah A, Venkaiah K, Brahmam GNV. Impact of feeding and breastfeeding practices on the nutritional status of infants in a district of Andhra Pradesh, India. Natl Med J India. 2012;25(4):201-6.

31. Mihrshahi S, Kabir I, Roy SK, Agho KE, Senarath U, Dibley MJ, et al. Determinants of infant and young child feeding practices in Bangladesh: Secondary data analysis of Demographic and Health Survey 2004. Food Nutr Bull. 2010;31(2):295-313.

32. Yazlle ME, Rocha JS, Mendes MC, Patta MC, Marcolin AC, Azevedo GD. Incidência de cesáreas segundo fonte de financiamento da assistência ao parto. Rev Saude Publica 2001;35(2):202-6.

33. Moore ER, Anderson GC, Bergman N. Early skin-to-skin contact for mothers and their healthy newborn infants. Cochrane Database Syst Rev. 2012;(5):CD003519.

34. Murray EK, Ricketts S, Dellaport J. Hospital practices that increase breastfeeding duration: results from a population-based study. Birth. 2007;34(3):202-11. DOI:10.1111/j.1523-536X.2007.00172.x

35. Ogunlesi TA. Maternal socio-demographic factors influencing the initiation and exclusivity of breastfeeding in a Nigerian semi-urban setting. Matern Child Health I. 2010;14(3):459-65. DOI:10.1007/s10995-008-0440-3

36. Oliveira MIC, Silva KS, Gomes Jr SC, Fonseca VM. Delivering rapid HIV tests results after delivery: a threat to breastfeeding at birth. Rev Saude Publica. 2010;44(1):60-9. DOI:10.1590/S0034-89102010000100007 
37. Organización Panamericana de la Salud. La alimentación del lactante y del niño pequeño: capítulo modelo para libros de texto dirigidos a estudiantes de medicina y otras ciencias de la salud. Washington (DC); 2010.

38. Pandey S, Tiwari K, Senarath U, Agho KE, Dibley MJ, Roy SK, et al. Determinants of infant and young child feeding practices in Nepal: Secondary data analysis of Demographic and Health Survey 2006. Food Nutr Bull. 2010;31(2):334-51.

39. Patel A, Badhoniya N, Khadse S, Senarath U, Agho KE, Dibley MJ, et al. Infant and young child feeding indicators and determinants of poor feeding practices in India: secondary data analysis of National Family Health Survey 2005-06. Food Nutr Bull. 2010;31(2):314-33.

40. Patel A, Banerjee A, Kaletwad A. Factors associated with prelacteal feeding and timely initiation of breastfeeding in hospital-delivered infants in India. J Hum Lact. 2013;29(4):572-8. DOI: $10.1177 / 0890334412474718$

41. Perez-Escamilla R, Maulen-Radovan I, Dewey $\mathrm{KG}$. The association between cesarean delivery and breast-feeding outcomes among Mexican women. Am J Public Health. 1996;86(6):832-6. DOI:10.2105/AJPH.86.6.832

42. Prior E, Santhakumaran S, Gale C, Philipps LH, Modi N, Hyde MJ. Breastfeeding after cesarean delivery: a systematic review and meta-analysis of world literature. Am J Clin Nutr. 2012;95(5):1113-35. DOI:10.3945/ajen.111.030254

43. Rowe-Murray HJ, Fisher JR. Baby friendly hospital practices: cesarean section is a persistent barrier to early initiation of breastfeeding. Birth. 2002;29(2):124-31. DOI:10.1046/j.1523-536X.2002.00172.x

44. Senarath U, Dibley MJ, Godakandage SS, Jayawickrama $\mathrm{H}$, Wickramasinghe A, Agho KE. Determinants of infant and young child feeding practices in Sri Lanka: secondary data analysis of Demographic and Health Survey 2000. Food Nutr Bull. 2010;31(2):352-65.

45. Senarath $U$, Siriwardena I, Godakandage SS, Jayawickrama H, Fernando DN, Dibley MJ. Determinants of breastfeeding practices: An analysis of the Sri Lanka Demographic and Health Survey 2006-2007. Matern Child Nutr. 2012;8(3):315-29. DOI:10.1111/j.1740-8709.2011.00321.x

46. Setegn T, Gerbaba M, Belachew T. Determinants of timely initiation of breastfeeding among mothers in Goba Woreda, South East Ethiopia: a cross sectional study. BMC Public Health. 2011;11:217. DOI:10.1186/1471-2458-11-217
47. Silveira RB, Albernaz E, Zuccheto LM. Fatores associados ao início da amamentação em uma cidade do sul do Brasil. Rev Bras Saude Matern Infant. 2008;8(1):35-43. DOI:10.1590/S1519-38292008000100005

48. Tamiru D, Belachew T, Loha E, Mohammed S. Sub-optimal breastfeeding of infants during the first six months and associated factors in rural communities of Jimma Arjo Woreda, Southwest Ethiopia. BMC Public Health. 2012;12:363. DOI:10.1186/1471-2458-12-363

49. Toma TS, Rea MF. Benefícios da amamentação para a saúde da mulher e da criança: um ensaio sobre as evidências. Cad Saude Publica. 2008;24 Suppl 2:S235-46. DOI:10.1590/S0102-311X2008001400009

50. Victor R, Baines SK, Agho KE, Dibley MJ. Determinants of breastfeeding indicators among children less than 24 months of age in Tanzania: a secondary analysis of the 2010 Tanzania Demographic and Health Survey. BMJ Open. 2013;3(1).

51. Victora CG, Huttly SR, Fuchs SC, Olinto MT. The role of conceptual frameworks in epidemiological analysis: a hierarchical approach. Int J Epidemiol. 1997;26(1):224-7. DOI:10.1093/ije/26.1.224

52. Vieira TO, Vieira GO, Giugliani ERJ, Mendes CM, Martins CC, Silva LR. Determinants of breastfeeding initiation within the first hour of life in a Brazilian population: cross-sectional study. BMC Public Health. 2010;10:760. DOI:10.1186/1471-2458-10-760

53. Weiderpass E, Barros FC, Victora CG, Tomasi E, Halpern R. Incidência e duração da amamentação conforme o tipo de parto: estudo longitudinal no Sul do Brasil. Rev Saude Publica. 1998;32(3):225-31. DOI:10.1590/S0034-89101998000300004

54. Widstrom AM, Wahlberg V, Matthiesen AS, Eneroth $\mathrm{P}$, Uvnas-Moberg K, Werner S, et al. Short-term effects of early suckling and touch of the nipple on maternal behaviour. Early Hum Dev. 1990;21(3):153-63. DOI:10.1016/0378-3782(90)90114-X

55. Wight NE. Hypoglycemia in breastfed neonates. Breastfeed Med. 2006;1(4):253-62. DOI:10.1089/bfm.2006.1.253

56. World Health Organization. Appropriate technology for birth. Lancet. 1985;2(8452):436-7.

57. World Health Organization. Evidence for the ten steps to successful breastfeeding. Geneva; 1998.

58. World Health Organization. Baby-friendly hospital initiative: revised, updated and expanded for integrated care. Geneva; 2009. Section 2. Strengthening and sustaining the baby-friendly hospital initiative: a course for decision-makers.

Article based on the doctoral thesis of Esteves TMB, titled: "Fatores associados ao inicio tardio da amamentação", presented to the Programa de Pós-Graduação Strictu sensu of the Escola Nacional de Saúde Pública Sergio Arouca - ENSP/Fiocruz, in 2014. The authors declare no conflict of interest. 